\title{
Dismantling Cultural Stereotypes: Journey Motif in Waris Dirie's Desert Flower
}

\author{
Dr. Victor Onyango Ouno, PhD \\ Maseno University, Nyanza Province, Kenya-40105 \\ DOI: http://doi.org/10.46382/MJBAS.2020.4401
}

Copyright: (C2020 Victor Onyango Ouno. This is an open access article distributed under the terms of the Creative Commons Attribution License, which permits unrestricted use, distribution, and reproduction in any medium, provided the original author and source are credited.

This research paper is a literary scrutiny of the use of the journey motif as formal strategy in the progressive dismantling of cultural stereotypes associated with women as represented in Waris Dirie's Desert Flower. The study explores the significance of the journey motif and how it is appropriated as a tool in the disassembly of cultural stereotypes in traditional African societies and female identity formation specifically in the Somalia society. This study, in particular, examines the physical, psychological and emotional facets of the journey motif and how these journeys shape or define female identity in a subjugated society. This study, therefore, demonstrates how the physical movements, psychological reawakening and emotional maturation help to (re)form women's fluid or lost identity. The study is predicated on Carl Jung's psychoanalytic theory of literature. The research work is based on textual analysis of the setting, plot development, Characterisation and use of language as part of the methodology in the interpretation of thematic concerns in the autobiography. In this literary work, the female protagonist undertakes many rigorous journeys which greatly delineate and determine who she becomes in a male-dominated society. The journey motif is, therefore, an effective technique that helps us to examine how the female protagonist forms her identity in a male-dominated and culturally suffocating Somalia society.

Keywords: Journey motif, Psychoanalysis, Stereotypes, Individuation, Emancipation, Dismantling.

\section{Synoptic Overview of Waris Dirie's Desert Flower}

Waris Dirie's Desert Flower is an autobiography that is divided into eighteen (18) parts, each dealing with a specific aspect of the narrator's journey towards maturity. The autobiography tells the story of a young girl who runs away from her rural home to chart a new cultural path. With the approval of an understanding mother, Waris leaves her rural home to forestall her father's attempt to marry her off to an old man. In her escape mission, she encounters a myriad of challenges ranging from the threat of possible attack by wild animals, predatory advances of sexual pests and physical attack. When she arrives in Mogadishu, she does not get the much-yearned-for reprieve. She is mistreated by her kin, one of her male cousin's attempts to assault her sexually and her willingness to travel to England to serve as a maid is met with resistance. When she leaves for London, she regains hope. However, upon her arrival, she discovers that more frustrations await her. Her hopes of joining a school are shattered as she is condemned to domestic slog. It is her uncle's departure from London that sets her on the true journey towards cultural emancipation. It is important to note that she titles this part "Free At Last." Despite the fact that she faces hosts of hurdles, she intrepidly cuts a niche for herself pursuing formal education, hunting for jobs to keep her going, undergoing an operation to find a normal reproductive life, modelling, documenting her real-life stories to inspire oppressed women and earning herself an ambassadorial role. Dirie uses her story to reveal the painful experiences of women in a chauvinistic society and dastardly effects of female genital mutilation.

\section{Cultural Stereotypes, Subversion and Quest for a New Identity in Waris Dirie's Desert Flower}

The journey motif is one of the most widely used literary devices in contemporary prose. The journey is a powerful symbol often used to represent a character's adventure leading to an epiphany, or some sort of self-realisation. This 
literary device can be applied in the background, working invisibly alongside the plot, or it can comprise the entirety of the plot itself so that all of the character's experiences are centered on the journey. There are a number of African works and writers spanning decades that have applied this device to their characters. Today the term is stretched to include "any [literary work] in which the hero takes a journey whose course plunges him into all sorts, conditions and classes of men ..." (Allen 18).

At the symbolic level, the physical journey can also become a metaphor for one's movement in the direction of self-individuation. It is therefore not right, often not even possible, to ignore the latent psychological undertones in an otherwise physical journey. This paradigm too has been used not for less for its scholarly aura and more for its functional utility. The basic assumption that runs through this definition is fairly commonsensical. It is that in any literary work, the protagonist's final inner state is qualitatively different from his initial inner state, the difference being the very definition of its plot or form. And it is in the dialectic, interplay or dynamics of the various constituents of his self and his external predicament that one individual novel differs from another.

C.G. Jung's concept of unified personality has perhaps been the most influential of all psychological concepts. Jung emphasises the need for a unified personality which is not split up into partial aspects. One's total personality is an organising, determining and complementary entity which urges one towards a union of opposites in their psyche and in return promises the meaningful, creative orientation of their potentials. It is an expression of an unknowable essence and can be called "the God within us." The start of one's whole psychic life seems to be inextricably rooted in this point, and all their highest and ultimate purposes seem to be striving towards it. Individuation is Jung's term for denoting the process of our getting to know one's personality in totality. Individuation aims at unfolding the personal unconscious and its false layers of complexes in order that the individual understands this part of one's self. It denotes an attempt on his part to get connected with the wholeness of his being that is the wholeness of conscious, subconscious and unconscious.

On his way to psychological wholeness, the individual has to encounter various archetypes. These include (i) persona or mask of the ego that stands between the individual's reality and society at large, (ii) anima/ animus or the male and female principles, anima being the feminine component in a male psyche and animus being the masculine component in a female psyche, and (iii) the "self" which is the emblem of wholeness. Although one can go on and list the four major stages - catharsis, elucidation, education and transformation - of one's progress towards individuation, it is more rewarding to concentrate on Jung's succinct observation on the nature and the value of individuation itself. It is rewarding because his emphasis is on the individual's "transitiveness" and becoming, and gives one the impression as if he were formulating the route for an arduous journey. Guerin's definition is explicit and thus:

Individuation is a psychological "growing up," the process of discovering those aspects of one's self that make one an individual, different from other members of his species. It is essentially a process of recognition - that is, as he matures, the individual must consciously recognise the various aspects, unfavourable as well as favourable of his total self. The self-recognition requires extraordinary courage and honesty but is absolutely essential if one is to become a well-balanced individual. (Guerin 137) 
The problem of female identity in the case of the African literature is linked with their cultural tradition. Folklore plays a significant role in creating consciousness among them. Ellison avers:

[Folklore] preserves mainly those situations which have repeated themselves again and again in the history of any given group. It describes those rites, manners, customs, and so forth, which insure the good life, or destroy it; and it describes those boundaries of feeling, thought and action which that particular group has found to be the limitation of the human condition. It projects this wisdom in symbols which express the group's will to survive; it embodies values by which the group lives and dies. (Ellison 171)

For all their differences, stories of the quest attest to the same fundamental feature of the human spirit: not only a perennial hunger for renewal but also an inextinguishable faith in its possibility. Many characters never accomplish their quests; some are defeated before they begin. Every quest is in proportion. The stronger the desire for the treasure, the more courageous the hero. The more valuable the treasure, the more difficult the journey to attain it. And when attained, the more truly valuable the treasure and the transformation, the more complete his rebirth. Any one requirement for balance along the way can cause the hero to fail. But for every protagonist who fails, another succeeds, and in so doing demonstrates the human potential for meaningful transformation, the ability of people to change their world and themselves for the better.

The study relies on Carl Jung's psychoanalytic theory. The ideas of Jung are documented in The Collected Works of Carl Jung. Carl Jung, like Sigmund Freud, was a medical psychologist. This paper is predicated on persona, anima or animus, shadow and self as eclipses of developmental stages in a person's quest for identity. It recognises that journeying is a predominant motif in Waris Dirie's works. Like Desert Dawn, Desert Children, Letter to My Mother, Saving Safa and My Africa - The Journey; Desert Flower depicts the mental and physical hurdles and tribulations that one must experience as part of their illumination integral to their character development, epiphany and self-realisation. In Lynn's words, "The nature of the self is identified and then reappraised and sometimes jettisoned in the narrated life story in order to achieve autobiographical coherence" (15). Lynn's argument resonates very well with Linde's position that "an individual needs to have a coherent, acceptable and constantly revised life story [for them] to exist in the social world with a comfortable sense of being a good, socially proper and stable person” (3).

The persona is primary stage in human growth. This study acknowledges that women exhibit extreme forms of submission, exaggerated versions of themselves, to satisfy the egotistical desires of men in the traditional Somalia arena. The traits they display, the façade, in their desire to impress men do not tally with their genuine miseries. When they are alone and have no one to impress, they acknowledge their subjugated positions; but in public they wear masks, personae, so that they are able to impose a desirable image of themselves onto others. Every society has subtle agreements about the manners which are acceptable, and those which are not; and it is expected that the individual will adapt to these requirements without anyone having to openly explain them. Women in the traditional Somalia community represented in Dirie's Desert Flower, for instance, are expected to behave as women should, with a certain subservience and weak-kneed loyalty that would be difficult for an ordinary person to achieve; any propensity for impatience or hostility would not be acceptable, and for good reason. 
It is unavoidably the distinct purpose of the persona to mollify all of the primitive urges, impulses, and emotions that are not regarded socially acceptable, and that, if we were to act upon them, would make us look foolish. Anyone with any sense at all sees through the façade; but they each participate in pretending that all this is real, so that society might carry on as normal. The difficulty with the persona arises only when one becomes so closely identified with his role that they lose all sense of self. At this point the damage is surely done: they will be entirely unaware of any distinction between himself and the world in which he lives. The result of an inflated persona, Jung warns, is a "shallow, brittle, conformist kind of personality" which is "all persona," with its excessive concern for "what people think." Such a person will sacrifice himself for the wishes of others without limit — not because he is a saint, but because he does not have the courage to refuse and endure conflict. As a child, Dirie, like her mother, this study argues, is forced to do what her father and, by extension, her Somalia culture demands of her.

The persona is the mark of obedience to expectations; it is the mask one wears to convince themselves, and others, that they are not bad persons altogether. Yet one cannot go beyond the persona before incorporating into their character those darker character traits which belong to what Jung calls the "shadow self." The shadow encompasses everything that one has denied in themselves and cast into oblivion. It refers to everything that the ego has refused to associate with itself, yet one can notice in other people — such things might include one's sexuality, spontaneity, aggression, instincts, cowardice, carelessness, passion, enthusiasm, love of material possessions. It embraces all those sins, dark thoughts, and moods for which one feels guilt and shame.

The shadow is ineludibly emotional in nature, because it has to oppose the rigidness of the ego; it holds its own autonomy, distinct from the conscious mind. Consequently, in being instinctive and irrational, the shadow is prone to psychological projection. One attributes to others all their evil and inferior qualities that they do not want to admit are in themselves. The argument advanced here presupposes that when one perceives a moral deficiency in others, they can be sure there is a similar inferiority within themselves. An overwhelming rage coming up in one when a friend reproaches them about a fault is an indication the fault is a part of their shadow, which they are unaware of. If one observes their umbrage towards themselves and others, and if they consider the moral aspects of their behaviour, then they have the opportunity to bring the shadow into consciousness, and achieve a renewed sense of strength and independence. This study contends that it is the projection of Dirie's shadow that prompts her father to marry her off to an old man when she is still "a valuable commodity."

Jung avers that the shadow nests the qualities of one's opposite gender. The anima is the archetype that connotes the fact that men have a minority of feminine qualities; and the animus expresses the masculine qualities within women. In every man there is a woman, and in every woman a man; or rather, there is the image of the ideal man or woman, which is, as a rule, formed in part by the experience of our mother or father, and by the influence of culture and heritage. Arguably, the ideas of feminine and masculine qualities are based on arbitrary stereotypes.

The anima, therefore, on the one hand, is the embodiment of all feminine tendencies, positive or negative, in a man's psyche. A positive expression of the anima might include sensitivity and empathy, capacity for loving relationships and a feeling for nature. But if the anima is rejected — that is, if a man represses those characteristics which might be considered classically feminine — the anima becomes deformed: feelings and emotions are replaced by 
moodiness, sentimentality, hysteria; fidelity becomes possessiveness; aesthetics become sensuality; tenderness becomes effeminacy; imagination becomes mere fantasising. The animus, on the other hand, is the epitome of masculine tendencies in a woman's psyche, such as strength of conviction, assertiveness, courage, strength, vitality, and a desire for achievement. But if the woman disregards her masculine edge then she is possessed by the animus: assertiveness translates to aggression and ruthlessness; and analytical thought becomes argumentativeness.

One would be inclined to suppose that the animus, like the anima, personifies itself in a single figure. But this, as experience shows, is true only up to a point, because another factor unexpectedly makes its appearance, which brings about an essentially different situation from that existing in a man. The animus does not appear as one person, but as a plurality of persons. ... The animus is rather like an assembly of fathers or dignitaries of some kind who lay down incontestable, "rational," ex cathedra judgments. On closer examination these exacting judgments turn out to be largely sayings and opinions scraped together more or less unconsciously from childhood on, and compressed into a canon of average truth, justice, and reasonableness, a compendium of preconceptions which, whenever a conscious and competent judgment is lacking (as not infrequently happens), instantly obliges with an opinion. Sometimes these opinions take the form of so-called sound common sense, sometimes they appear as principles which are like a travesty of education: "People have always done it like this," or "Everybody says it is like that." (The Collected Works 207)

Just like the shadow, the archetypes of the anima or animus have their own autonomy, and are independent from our conscious mind. Thus the anima/ animus can be projected in the world so that they appear to be some qualities of a specific man or woman. In the presence of the anima, or at least a good imitation of anima, a man feels a peculiar familiarity with her, as if he has known this woman for all time; in some cases, the energy between the two is intoxicating, to the degree that one might say he has fallen in "love at first sight." In reality, it reflects the man's entrapment with a deception, with the image that he has projected onto another woman. It is only when the mirage of the projection disperses will he realise himself as a fool. The withdrawal of the projection signals the recognition of the anima as a force within oneself. When a man is "animated," he ostensibly reconnects with a divine power in the inner world - which may exhibit itself as a creative ability, or a sensitivity for the natural world — which is always been within them and only requires awakening. The anima is encapsulated in the figure of woman, the presence of the feminine or the prompting hand of a woman. The anima embodies all the feminine psychological tendencies within the man, such as prophetic hunches, intuitions, moods, receptivity, capacity for personal love, a feeling for nature and a man's relation to the unconscious. The woman, in what is akin to ancient times, is used as a diviner to make out the divine will, to translate it, and to make a connection between man and the spiritual world. The anima, to this end, connects a man to the great unknown.

Overcoming the persona, and integrating the shadow and the aspects of the anima/ animus archetypes into one's character, gives one access, Jung believes, to the deepest and highest reaches of the psyche, the archetype of wholeness - which Jung names the "Self," the most significant of all the archetypes. "The Self embraces," Jung writes, "ego-consciousness, shadow, anima, and collective unconscious in indeterminable extension." The self, in 
Jung's view, symbolises the "God in us" and, as such, the entirety of our innate capabilities: "who we are," "what we once were," and "what we could potentially become." Jung posits:

The meaning and purpose of the process is the realisation, in all its aspects, of the personality originally hidden away in the embryonic germ-plasm; the production and unfolding of the original, potential wholeness. The symbols used by the unconscious to this end are the same as those which mankind has always used to express wholeness, completeness, and perfection: symbols, as a rule, of the quaternity and the circle. For these reasons I have termed this the individuation process. (The Collected Works 110)

Somali women writers - Amina Said Ali, Amran Mohamed Ahmed, Halima Godane and Shadya Yasin among others - display a poignant, ironic and profound collective voice against the institutional subjugation of women in the traditional Muslim society. Apart from challenging what Jacques Derrida regards as phallogocentrism of discourse in Somali writings amidst the growing consciousness of female marginalisation, social discrimination, sexual oppression, gender distinction and bigotry; these writers blatantly question the patriarchal territoriality, reject gender stereotyping and dismantle the oppressive social and physical segregation of the two sexes - the superior, authoritative and domineering men, and the subaltern, sub human, self effacing women. Consequently, women's struggle for freedom from the religious and social prescripts, self-identity and realisation, pursuit for equity and freedom occur as recurring themes in the contemporary English writings by Somali women.

Waris Dirie is a peripatetic diasporic writer who uses her life writings to depict the plight and to raise her voice against the subaltern status of women especially the Muslim women across the globe. Through her autobiography, Dirie explores matters that are unique to women - their sheer misuse, their unresponsiveness in the face of bigotry, genuflection to traditions and norms, and the widespread social unfriendliness and exclusion. Her works also expose the tensions occasioned by the binaries of antiquity and modernity; the ancestral and the diasporic location of displacement, and between the defeatist mentality of conservativeness and exploring cultural transcendence. This paper titled "Dismantling Cultural Stereotypes: Journey Motif in Waris Dirie's Desert Flower" is an attempt to explore how Dirie through her autobiographical writing tries to underscore the subjugation of women in the society and accentuates why women themselves need to revolt against the ensuing bias and oppression perpetuated by gender politics. Concomitantly, she also highlights the adversities, repression and the incessant trials and tribulations which women, especially those belonging to orthodox patriarchal families, face throughout their lives. A cosmopolitan Muslim herself, Dirie presents the confluence of three cultures - Somali, British and American, to underscore the power dynamics which robs women of their identity and self-esteem.

Through her work, she demonstrates the flagrant violation of their human rights in terms of freedom of expression, choices and decisions. A votary of equality and identity for the suppressed and marginalised womanhood, she raises basic humanistic and feminist issues and questions the Radicals for undermining the competence and potential of women. Although Desert Flower pronouncedly exposes the vicious polarised sensibilities in the Somalia society which she has studied and observed from close quarters, her pragmatic vision encompasses the plight and predicament of all those who lead a life of oblivion and anonymity behind both visible and invisible yet invincible personalities outside the Somalia society as well. Lamenting the lack of freedom and opportunity to 
women, Dirie uses her autobiography as a tool to unveil all those women who are relegated only to hearth and home, and subjected to ceaseless mental and physical harassment and agony by the obliterating chauvinistic male hegemonic influence. Thus, although her focus is more on the Somalia women, her vehement denunciation and acerbic outburst against institutionalised victimisation of women is inclusive of all women in general.

The "desert" symptomises the burdens that have been placed on the woman's back, rendering her identity crushed and thus the need to embark on journeys to reclaim it. The rudimentary motifs of physical journeys such as exodus, hindrances associated with movements and return have been identified and regarded as instrumental components in probing the female narrator's quest for a new identity, success in this pursuit and embrace of new self. Jung's tenet of the 'unconscious' as brought forth through dreams and mental states becomes necessary in tracing the psychological and emotional movements of the characters.

The physical journeys in Desert Flower represent the writer's movement towards self-individuation. When the story begins, she is "running away" from various manifestations of her "anima" - a forced "marriage contract," "growing up with animals" like Guban who take advantage of the innocence of young girls to satisfy their animalistic sexual desires, "a nomad's life" that equates women to commodities for sale, an outmoded culture that regards genital mutilation as the only pathway to "becoming a woman" and a tradition that does not permit a woman's desire for self-expression. Her journey to Mogadishu gives her a chance to learn rudimentary defense mechanisms against sexual predators. She evidently stops the truck driver from using her as an object of sexual gratification. Unlike her past experience with Guban, she musters the courage to fight off the driver. Beaten to a frazzle, the driver is unable to predate on her. It would appear that her ability to face wild animals on her way to Mogadishu catapults her to bring her shadow into consciousness. She admits that even though "she was sick with fear of what might happen, [she] decided to hitchhike again, because [she] knew [she] needed to get as far away as possible from the truck driver and [his ilk]" (Desert Flower 9). This confrontation marks a significant turning point in her life. Her subsequent movements progressively drive her to self-realisation.

Dirie's vociferous outcry against this ill-treatment and suppression is most potently encased in the first two parts of her autobiography "Running Away," "Growing up with Animals," "A Nomad's Life," "Becoming a Woman," "The Marriage Contract," "On the Road," "Mogadishu," "Going to London," "The Maid," "The Doctors," "Passport Dilemma," "The Big Apple" and "Thoughts of Home." Exploring primarily the matrix of home, cultural displacement, communal conflicts and gender politics, Dirie highlights the unmitigated suffering and struggle of women for empowerment and emancipation and the dichotomy between the ideal state of affairs and the reality. The first two parts, for instance, enunciate the atrocities and injustice meted out to the women who remain passive stakeholders in society and become the mute victims of emotional and physical violence generated through the archaic Somali culture. Dirie rightly perceives it as a potent mode of seclusion and an instrument of subjugation. Regarded by the Muslims as an epitome of feminine modesty, the hijab or Veil is, in fact, a means to control the lives of women on the flimsy pretext of protection. Not only does it amount to physical segregation of women, but it also compels women to conceal their form and cover their heads and bodies. 
The persona is a complicated system of relations between the individual consciousness and society, fittingly enough a kind of mask, designed on the one hand to make a definite impression upon others, and, on the other, to conceal the true nature of the individual. That the latter function is superfluous could be maintained only by one who is so identified with his persona that he no longer knows himself; and that the former is unnecessary could only occur to one who is quite unconscious of the true nature of his fellows. Society expects, and indeed must expect, every individual to play the part assigned to him as perfectly as possible, so that a man who is a parson must not only carry out his official functions objectively, but must at all times and in all circumstances play the role of parson in a flawless manner. ... Our society is undoubtedly set on such an ideal. It is therefore not surprising that everyone who wants to get on must take these expectations into account. Obviously no one could completely submerge his individuality in these expectations; hence the construction of an artificial personality becomes an unavoidable necessity. The demands of propriety and good manners are an added inducement to assume a becoming mask. What goes on behind the mask is then called "private life." This painfully familiar division of consciousness into two figures, often preposterously different, is an incisive psychological operation that is bound to have repercussions on the unconscious. (The Collected Works 192-3)

Dirie's mordant outburst at the religious intransigence manifests most potently in her condemnation of the misinterpretation of Somalia culture as a safety against prying eyes of strange men. Not only does Dirie make an overt protest against the despotic proscription of the Islamic society, but she also empathises with all those women who are suffocated, confined and trapped by the torpidity of village life and the anachronistic social constructs under the hegemonic control of the religious fundamentalists. Under the garb of religious diktats, unwarranted and iniquitous rules are devised which are detrimental to the psyche and individuality of women.

A critique against the institutionalisation of irrational and absolute power wrested in the hands of men, Desert Flower blatantly censures the Muslim male dominion which is despotic and brutal towards the female sex. Dirie denounces the hypocrisy of those men who instead of reining in their own animalism take pride in veiling and incarcerating women. The suppression and exploitation of women which she talks about is not restricted to the Muslim society but has a menacing presence in the outside world as well. Consequently, both the literal and metaphorical Desert Flower may be deemed as a two-edged weapon for it not only impedes the assimilation of the self in the society but also strains and sifts the outer world and allows only a fraction of it to reach the self, hidden behind the obligatory veil. Moreover, it has a far-reaching and incisive connotation of women as propagators of evil and promoters of lust. Somali traditional culture is a regressive tool and the consequence of its uncritical consumption is deprivation and degeneration of the self, leading only, as Dirie rightly says, "Although I didn't realise it at the time, I knew a lot about how to live quietly with suffering in the passive, helpless manner of a child" (Desert Flower 48).

What perplexes Dirie further is that even marriages become a pretext of intellectual and sexual exploitation. Ideally a relationship of lifelong bonding and sharing, in reality marriages here entail a business deal between men involving monetary transactions or sheer convenience. Denied any say, preference or individual choice, women have no option but to accede to the edict and endure a life of ignominy and suffering. Dirie potently portrays the 
insalubrious business prepositions where the sale and purchase of women is a norm even in the traditional Somali Culture. Girls are kept "under lock and key" and it is men who hold "the key" and they cannot come out until men "say [they are] ready" (Desert Flower 54). Thus forced and hurdled into awkward unions, there is no reprieve for her from this forced marital slavery. As the title aptly suggests, the vulnerable woman is abandoned in a "desert" in this vicious cycle where man by virtue of being physically strong, assertive, economically independent and socially empowered continues to be the cause and propagator of unmitigated suffering and grieving for the woman. Perhaps, death is the only escape for them. Dirie's friend, Shukrin, a thirteen-year-old girl, is married off without her consent. She posits thus:

As a girl in Somalia, I never thought about marriage or sex. In my family - in our whole culture - nobody ever talked about any of that. It never, ever, came to my mind. My only thoughts on boys were competing with them to see who could be best at caring for the animals, racing with them, and beating them up. The only thing anyone ever said on the topic of sex was "Be sure you don't mess with anybody. You're supposed to be a virgin when you marry." Girls know they will marry as a virgin, and will marry only one man, and that's it. That's your life (Desert Flower 52).

In the way, Dirie is married off for upsetting the cultural conventions. She grows into a "rebel, a tomboy, sassy and fearless." She even earns a reputation for exhibiting these "masculine" traits. She recalls that her father "had to find [her] a husband while [she] was still a valuable commodity, because no African man wanted to be challenged by his wife" (Desert Flower 56). Dirie's attraction to Jamah does not count in any way; she is forced to marry Jamah's father. The "thought of having to sex with a disgusting old man" and having to remain tied to him to death because "widows do not remarry" add to Dirie's misery, but she cannot protest because her father is "determined to get rid of her and get his FIVE camels" (59).

Dirie, accordingly, criticises the partiality of the domestic spaces within the chauvinistic society which peripheralises women and reduces them to agents of sheer drudgery. Besides, the patriarchal society perceives them merely as objects of sexual pleasure. This cacotopia dominates Dirie's autobiography. The intruder, a pervert who rapes Dirie's sister, Fauziya, leaving her "covered with white sticky semen" does not apologise when he is caught. This "sick bastard" draws out a knife and stabs the narrator's father five times for confronting him over sexual assault (53). Men abhor justness of domestic spaces. They do not want to be judged on the basis of the moral standards they themselves set. Morality, it appears, is a selective affair. This is a lucid indication that this licentiousness is deep-rooted. Aside from being objects of sexual gratification, women are facilitators and breeders of posterity.

Dirie's journey to Mogadishu, which largely covered in "On the Road," reveals that prejudice against women is not limited to rural Somalia communities, it pervades the urban areas as well. Patriarchal conformist Moslem families enforce discriminatory and restrictive decrees on the female sex. Notwithstanding that she appreciates the gorgeousness of women scarves, she ridicules the Moslem society for insisting that women must put them on even when circumstances clearly dictate that they should not: "I saw many Moslem women with scarves draped over their heads, the dark veils covering their faces altogether. I stared at them, wondering how they could find their 
way. The city sparkled in the bright sun and all colours seemed electrified" (Desert Flower 70). The world may be changing for the better but the radicals, irrespective of religion, resist change and any attempts at initiating value-oriented modernity. Insisting on conformity to age old obsolete customs, they vociferously condemn, impede and resist any attempts to initiate women emancipation in the society.

Dirie's Desert Flower is an unsparing indictment of Somalia society. The autobiographer appears agonised by the distortion and misinterpretation of religion and even questions its justness. Ideally the guiding force in life, it in place of giving succor and justice becomes an instrument of injustice, exploitation, violence and gratuitous oppression of women. She indicts the suppressive prescriptions of the Islamic social and religious setup which denies a dignified identity to women, forcing them to pander to the male ego and fancies. Deeming it as a brazen desecration of women's freedom to dress and express, she uses her autobiography to subtly protest against this tradition. Dirie ridicules the convention of ideal demeanor expected from women in "On the Road."

Not only does Dirie's Desert Flower address gender issues pertaining to the limited space available to women across societies, but it also encourages the oppressed and marginalised women to embark on a journey of introspection, self-discovery and reincarnation. It eulogises the spirit of womanhood and urges them to revolt and break free from these constraining and humiliating social constructs. Dirie's first meeting with Dana reveals her exceptional, even Promethean gallantry. When Dana leaves, she refuses to "let him get away that easily." She follows him, sits next to him, scolds him for being insolent, initiates their conversation and generally takes charge of the new relationship. She observes: "I explained that if I wanted something I went after it, and for some reason - for the first time in my life - I very much wanted a man” (Desert Flower 214).

The journey to Mogadishu is "excruciatingly slow" and deliberately so (Desert Flower 69). Dirie uses this painful journey to demonstrate the hurdles that women face in their efforts to dismantle cultural stereotypes. The slow pace of progress is frustrating. Apart from denouncing the cultural paradigm of treating women as commodities and objects of sexual gratification, Dirie also highlights the glaring absence of justness in religion which should in principle be above all man-made discriminations. It, in fact, supports and proliferates bias against women. By denying them denying them the opportunity to dress comfortably and independently on the pretext of upholding standards of feminine decency, the misconstruction of woman as a temptress whose very sight is sinful for the forthright male is reinforced and ironically God seems to have given into man's whims and fancies. Such a fallacious proliferation is confined not only to the mother land but has numerous takers in the diasporic world too. In fact, religious orthodoxy in terms of customs, traditions and conventions has typically been used by men to control women. The scenario is much the same even in the diasporic homelands. The exposure to a more liberal culture abroad especially in the west is deliberately negated by instilling the fear of retribution for not adhering to religious conventions.

In fact, the implanted inferiority of the "fairer" sex, lack of opportunity and social security, inaccessibility to liberal cultural values coupled with the insistence on upholding national, cultural and religious identity further impede women emancipation. Consequently, even during the process of acculturation, those who wish to break free from cultural and social bondage to assimilate with the other cultures find themselves torn between not only 
the two cultural polarities, gender binaries and racial prejudices but also by the fear of retribution filled in their minds by the custodians of religion. This biased perception of religion is indeed worrisome for it forces one half of the society to be wary of the other, lead a life of deprivation and remain at the mercy of men-folk for their sustenance. While lamenting the issues of gender binaries operative within the orthodox familial and social set-up which refuses to give up conventionality to embrace a more liberal and emancipated setup, Waris Dirie's autobiography also highlights the cultural incommensurability in the diasporic environs.

Dirie undoubtedly unravels the self-effacing and deadening impact of such restrictions on the consciousness and individuality of women across the world. Relegated to mere domestic drudgery, women are expected to cater to the needs of the family and to be at the beck and call of their fathers or husbands and most often than not they submit to their fate. In fact, these curbs and restrictions have been so internalised by women down the centuries that they accept and conform to these and in turn become perpetuators of social discrimination and aggression against other women in the family. Devoid of option and voice themselves, they have no option but to mould their daughters to accede to the patriarchal laws. "The Marriage Contract" depicts how this haplessness seeps into the daughters who too submit to their fate without resisting or rebelling. Shukrin, a thirteen-year-old girl, is married off in this manner. "This was common practice" and Shukrin, like other vulnerable girls, cannot question the decisions of her father "as such a question was considered none of [her and, by extension, women's] business" (Desert Flower 51). When Dirie's father decides to marry her off to an old man, her mother admits to not being in a position to oppose her father's decision: "Well, my darling, it's out of my hands. What can I do? It's your father's decision" (Desert Flower 60).

Congruently, Dirie, in "Mogadishu," quite scathingly, summaries the ennui and the monotony of the life of a common woman whose liberty is confined to a small house - "having [her] view of the sky blocked by a ceiling, the space [she] could move around in limited by walls, the brush and animal smells of the desert replaced by the sewage and carbon monoxide smells of a crowded city" and for whom the taste of water is a sign of luxury (Desert Flower 76-77). It is, indeed, a ubiquitous phenomenon that a woman, far from being appreciated for her talent and adroitness in managing the household chores, is often ridiculed, cursed and abused. Dirie admits that her father could "help with the animals but he couldn't lift a finger to help with the cooking, or clothing, or making baskets, or taking care of children. This was woman's work and Mama's problem" (80). Like her grandmother, her mother could not even complain for "walking for miles and miles" (Desert Flower 75). This starkly depicts the plight of the marginalised woman, the 'other' in the society. In Dirie's own confession, the woman is looking after everyone else but no one is taking care of her. Dirie's outburst is reminiscent of Simone de Beauvoir's assertion that "One is not born a woman; one becomes one.... the situation of woman is that she... a free and autonomous being like all creatures...nevertheless finds herself living in a world where men compel her to assume the status of the other."

Relentless in her condemnation of the stereotyping of gender roles, Dirie, like most other feminists, deplores the lack of opportunity and freedom given to women. Her autobiography distressingly depicts the plight of 
innumerable women whose destiny is sealed by men while they remain mute spectators, coerced to follow the diktat. The poignant portrait of Dirie's circumcision experiences in "Becoming a Woman" clearly illustrate this:

My father was growing concerned, because Aman was reaching marriageable age, but no marriage could take place unless she had properly "fixed." The prevailing wisdom in Somalia is that there are bad things between a girl's legs, parts of our bodies that we're born with, yet are unclean. These things need to be removed - the clitoris, labia minora, and most of the labia majora are cut off, then the wound is stitched shut, leaving only a scar where our genitals had been. But the actual details of the ritual cutting are left a mystery - it's never explained to the girls. You just know that something special is going to happen to you when your time comes.

(Desert Flower 40)

This illustration demonstrates how the Somalia society dehumanises women. They are depicted as things that have to be "fixed" before they are married off. This "fixing" is done to massage the prospective husband's ego. Before a woman's genitalia is mutilated, she is regarded as unworthy. As such, no man can marry her. That the natural state of their reproductive organs makes them "unclean" is ludicrous as it is demeaning. Circumcision drastically transforms their lives yet they do not have the right to question why it is done. It mutilates the woman's genitalia and leaves a "scar" yet it is ironically regarded as a "special thing."

Female genital mutilation actually marks the beginning of a woman's physical and emotional distress. Dirie's first meeting with William in 'The Doctors' illustrates traumatising effects of this obsolescent practice. She rejects his advances. She adumbrates doom; any relationship with a man who does not understand her culture will "be angry" and they will "have a fight" (Desert Flower 149). Female genital mutilation makes her different from "other girls." She is not able live a normal life. The fact that other girls "pee quickly in a heavy stream" amazes her because it takes her "ten minutes to urinate." This agonising ordeal pushes her to the position of the "other.' She loses her self-esteem and practically finds it difficult to initiate any meaningful relationship. For over six years, she regards family prospects as a shattered dream:

And someday I hoped to have a husband and a family of my own. But as long as I was sewn up, I was very much closed to the idea of a relationship, shut away into myself. It was as if the stitches prevented any man from any me-physically or emotionally. (Desert Flower 150)

It is her decision to reveal her distress to Marilyn that sets her on the path towards rediscovery. After going through multiple psychological journeys, she finally pulls her pants down and shows her horribly mutilated genitalia. It takes her a lot of psychological effort to convince herself that she needs to meet Dr. Macrae. This experience demonstrates that the archetype of the self is the origin of Dirie's impulse towards self-realisation; it is the single point from which her character and her personality matures as she grows older — just as a seed holds the whole potential future of a flower. It is the Self that brings forth what Jung called "the process of individuation," which begins from the potential of childhood to an expansive journey of self-discovery, whereby one consciously and gradually integrates the unconscious aspects - the parts of ourselves that we have refused to confront — of one's personality into the whole. Jung believed that it is the end purpose of human life to experience this coming together 
of the whole, to fully integrate and make conscious everything about ourselves that was hidden in the shadow. This end is the fullest expression of one's character, and allows one to hold firm their individuality against the collective mass unconscious. For Dirie, the surgical procedure marks the end of slavery:

Within two or three weeks I was back to normal. Well, not exactly normal, but more like a woman who hadn't been circumcised. Waris was a new woman. I could sit down on the toilet and pee-whoosh! There's no way to explain what a new freedom that was. (Desert Flower 158)

As a crusader for rights for women, Dirie urges women to take up cudgels against such atrocities and forced subalternity. In fact, in portraying their plight through her life writings, she shows her allegiance to the imperative need of breaking free from the shackles of restrictive and repressive social milieu. In fact, Waris Dirie belongs to rather small group of writers who openly challenge the patriarchal power structure. She rightly perceives this female subjugation as not culture or religion specific but as an enforced slavery that permeates both time and space, as pervasive in the diasporic world as in the homeland. Her stand is vindicated by the fact that even in the socially awakened, developed and liberated western society, there are innumerable instances of domestic violence, exploitation and servitude. Ironically, despite avowals of liberty and equality, the west or the so-called modern society is not free from gender disparity. Even in civilised societies, as Dirie rightly points out in "The Big Apple," men expect women to be subservient to them. Nigel resorts to emotional blackmail, psychological abuse and even outright violence to put a gag on her. He tells Dirie to her face that she is "not going to be free, unless [she comes] up with the money she owes him" (Desert Flower 218). He has the effrontery to proclaim that Dirie's "baby is going to be a bastard for the rest of his life" (219). As if this is not intimidating enough, he threatens to kill her. He turns violent when Dirie visits him alone:

I knew I had to get out of there immediately, because this time he'd really gone over the edge. I bent over to pick up my bag from the floor, and he shoved me from behind. I went crashing into the stereo face first, then rolled off onto the hardwood floor, landing on my back. I just lay there, scared to move. Oh, my God-my baby! I was so paralysed with fear that I'd harmed baby (Desert Flower 219).

The recalcitrant "self" that Dirie presents in her autobiography, while being critical of the hypocrisy of the socio-cultural dogmatism, is herself a victim of patriarchal marginalisation. The reality in many African countries like hers paints a damning picture of deep-rooted prejudice against women. Denouncing socio-economic sanctions against women in "The Ambassador," she poses a raft of rhetorical questions that point a bleak future for the rural womenfolk:

The reality is that I'm the lucky one. What about the girl back in the bush, walking miles and miles to water her goats, while she's in such pain from her period that she can barely stand up straight? Or the wife who will be sewn back up with a needle and thread like a piece of cloth as soon as she gives birth, so her vagina will remain tight for her husband? Or the woman nine months pregnant hunting for food in the desert to feed her other eleven starving children? Or what happens to the new wife who's still sewn up tight, and it's time for her first 
baby to be born? What happens when she goes out into the desert alone, as my mother did, and tries to deliver it by herself? (Desert Flower 225)

The questions demonstrate the need for urgency in tackling gender-based biases. She understands the obvious answers to these fundamental questions: "Unfortunately, I know the answer to that question. Many bleed to death out there alone, and if they're lucky, their husbands will find them before the vultures and hyenas do" (Desert Flower 225).

The section "Free At Last" marks the dawn of a new era for Dirie. It is important to note that her journey does not stop, rather it continues. She is no longer bound by her uncle's rules. No one curtails her freedom. Moving from one store to the next, she discovers the "enormous variety of choices" (Desert Flower 119). The departure of her uncle affords her the chance to make her own choices, her decisions without fear. She walks into several stores, tries new things and derives pleasure from this adventure. She understands that she has to live on the little money she "squirrelled away from her maid's wages" but she must also dress decently. This speaks of a transfigured psyche. Although Dirie takes charge of her life as nobody yells at her "to milk the goats, feed the babies, make the tea, scrub the floors and scour the toilets," she single-handedly encounters the real hardships of a new socio-cultural and economic environment.

Dirie spends the whole day journeying from shop to shop in a bid to explore new experiences. When she meets Halwu, she makes another fruitful discovery: she was not the only woman who had gone through a lot of social hardships. This discovery revitalises her resolve to soldier on. She desires to go back to Somalia, her motherland but she understands only too well that there are no opportunities at home. She observes: "Without saying it, we both knew: we missed our home and families, but what opportunities did we have there? Being traded for camels? Becoming some man's property? Struggling everyday just to survive?" (Desert Flower 120). These rhetorical questions highlight the stark realities about traditional African settings. They also spotlight the binaries of nationalism and social-economic reality.

Incontestably, Dirie, like Amina Said Ali, Amran Mohamed Ahmed, Halima Godane and Shadya Yasin, poses a threat to the hostile hegemonic paradigm of patriarchal social setup. They protest against societies where all privileges pertaining to education, health, subsistence and respect are reserved for the men folk and women exist on the margins-unwanted, uncared for and unsung. Cognisant of the dichotomy between the isolation, the seclusion, the confinement and the slavish existence of women in the African continent on one hand, and the growing number of liberated, emancipated and empowered women in the west on the other, Dirie, like her ilk, is intolerant of the polemics of gender inequality. Consequently, through her works she expounds and explicates this ubiquitous patriarchal flagellation. However, she does not sentimentalise or glorify women travails. She rather celebrates their feminine mystique and insurmountable strength to endure by her assertion in "The Ambassador":

After going through the cycle of womanhood that began prematurely with my circumcision at age five, and came full circle with my baby's birth when I was about thirty, I had even more respect for my own mother. I understood what incredible strength the women in Somalia possess to bear the burden they carry simply 
because they're born female. As a woman living in the West, I struggled to do what I had to do, and some days didn't think I'd make it: trying to work scrubbing floors at McDonald's when my periods were so painful I thought I'd pass out. Having surgery to open the crude scars of my genitals so that I could urinate properly... (Desert Flower 224).

Optimistic that things will change for the better, Dirie exhorts women to fight for their own rights and individuality. She prompts women to unleash the latent energy and strength against their oppressors. Her painful past does not deprive her of objectivity. Her perception of tradition and oppression remains unjaundiced. She also acknowledges that some of these oppressors, like her father, are "victims of their own upbringing, cultural practices that have continued unchanged for thousands of years." These outmoded cultural practices, she admits, are not unique to Somalia; the problems she has coped with "also plague millions of girls and women throughout the world" (Desert Flower 225). Her suffering and the painful experiences of her ilk are emblematic of the pains of many women in traditional African countries. She understands that genuine solution lies in women empowerment as she notes that "we know women are not animals in heat, and their loyalty has to be earned with trust and affection rather than barbaric rituals ... the time has come to leave the old ways of suffering behind." Her concluding remarks in "Thoughts of Home" clearly suggests renewed hope in the face of self-discovery:

I just pray that one day no woman will have to experience this pain. It will become a thing of the past. People will say, "Did you hear, female genital mutilation has been outlawed in Somalia?" Then the next country, and the next, and so on, until the world is safe for all women. What a happy day that will be, and that's what I'm working toward (Desert Flower 238).

What is particularly striking in Dirie's autobiography is her daring objectivity. She understands that she is treading on an unconventional cultural path. She knows the traditional labels associated with women who subvert the cultural norms. This autobiography celebrates the new beginning, the rise of a phoenix out of its own ashes for a woman, female "fighter" who is ready to "rip off a man's balls" to liberate herself from male dominance (Desert Flower 220). Dirie dares to declare her dissent, despite being defiant, and ultimately finds her own moorings and identity. Dirie urges women to cast off nationality and gender to explore afresh their space, identity and life. She loves her homeland - Somalia - and her patriotism is unquestionable, but this does not deter her from challenging the obsolescent Somali culture. It does not stop her from adventuring, from journeying beyond Somalia borders to exploit opportunities that are available to women and which would, hitherto, remain elusive if women stuck to the confines of their traditional localities. Hers is a dynamic and pragmatic feminist voice in life writing which questions the unjust social practices which impede the psychological and intellectual awakening of women and inflict a rather paralysing, numbing and deadening influence on the psyche of women. This aspect is most explicitly presented in Dirie's initial remarks in "Thoughts of Home":

Because I criticise the practice of female genital mutilation, some people think that I don't appreciate my culture. But they're wrong. Oh, I thank God every day that I'm from Africa. Every day. I'm very proud to be Somalia, and proud of my country. I guess some other cultures might consider that a very African way of thinking - you know, being proud for nothing. Arrogant, I guess you'd call it. 
Other than the circumcision issue, I wouldn't trade with anyone the way I grew up. Living in New York, although everyone talks about family values, I've seen very little of them. I don't see families getting together like we did, singing, clapping, laughing. People here are disconnected from one another; there's no sense of belonging to a community. (Desert Flower 234)

The foregoing illustrations demonstrate Dirie's literary boldness. She goes against the grain of cultural stereotyping. She joins the league of Chimamanda Ngozi Adichie who warns against the danger of a single story. Dirie's standpoint here is akin to the observation that Adichie's female protagonist Olanna makes in Half of a Yellow Sun when she visits her aunt. Olanna, Adichie's mouthpiece in the aforementioned novel, relishes the naturalness of her aunt's house as it atypifies her father artificiality. Like Adichie, Dirie presents a balanced view of African culture. She presents a positivistic outlook of African culture even as she denounces female circumcision as an outmoded practice.

Undoubtedly, it is only through self-realisation and re-invention that a woman can succeed in establishing her individuality and freedom from the constrictive and proscriptive social and religious norms. Dirie attests to the proposition that the autobiography "is actually the core of self-identity in modern life" (Giddens 76). Thus, Desert Flower while discreetly rebellious gives a whiff of the prophetic and imminent change in the perception and psyche of the society. For she is confident of the potential of women. In a bid to awaken them to their own strength, she prods them to determine their purpose in life, their divine plans and the reason they have been kept alive. She anticipates this revolution which will accord equality and freedom to men and women. Her words "an uninhibited feeling of freedom and joy" (208) may be construed as prophetic for there are visible signs of change. Fundamentally, voices like that of Dirie show hope of better tomorrow for the "nomads" and women "in the desert," the silenced echelons of society, who are the dehumanised victims of exclusion and partial social and cultural constructs. She is a voice of "the woman in the desert [like her mother] with no money and no power," "women on the continent of Africa [who] live their lives in pain," and "nomads [who are condemned to] a ritual of ignorance" and urgently somebody "to speak out for [them]" (Desert Flower 225). In highlighting the feudal orthodoxy in the world, she unearths the tension and discord between the idealistic and the factual status of women- their subaltern existence at the margins of the society. However, her anguished outcry is not merely aimed at exposing the discord but an attempt to merge the two binaries so as to reconcile the apparently insuperable dichotomy between the ideal and the real state of women in our society.

The foregoing discussion demonstrates the efficacy of journey motif as formal strategy in the progressive dismantling of cultural stereotypes associated with women in traditional African societies. Confinement to a particular physical space translates to cultural stagnation and is detrimental to a woman's psychological growth. To break away from cultural shackles and stereotypes in patriarchal societies, one has to move out their traditional locality. Dirie's is the story of transition from patriarchal subjugation to free environments where women are able to form new identities. The completion of the journeys helps them transcend socio-cultural subjugation. This transcendence translates to a liberated woman. As Dirie recounts her maturation journey, she projects a cathartic rebuilding of the self. The paper additionally investigates the autobiographer's subversion of gender roles in a 
conservative society where men project themselves as superiors. Waris is an embodiment of modern women who are valiantly playing pioneering roles in their advocacy for liberation from obsolescent cultural shackles. The candidness with which the nitty-gritties of Dirie's personal life are recounted accords Desert Flower a spell-binding quality. This story has a pace-setting quality too because voyages presented in this autobiography were traditionally the province of male protagonists.

\section{Works Cited}

Abrams, Lynn. "Liberating the Self: Epiphanies, Conflict and Coherence in the Life Stories of Post-War British Women.” Social History, vol. 39, no. 1, 2014, pp. 14-35.

Allen, Walter. The English Novel: A Short Critical History. New York, 1954.

Beauvoir, Simone. The Second Sex. Penguin, 1984.

Dirie, Waris. Desert Flower. Virago Press, 2001.

Ellison, Ralph. Shadow and Act. Random House, 1964.

Giddens, Anthony. Modernity and Self Identity: Self and Society in the Late Modern Age. Cambridge, 1991.

Guerin, Wilfred et al., A Handbook of Critical Approaches to Literature. Harper 6. Row, 1966.

Jung, Carl. The Collected Works of Carl Jung, edited by Herbert Read et al, Princeton University Press, 1972. Linde, Charlotte. Life Stories: The Creation of Coherence. Oxford, 1993. 